\title{
Upstream-downstream linkages of hydrological processes in the Himalayan region
}

\author{
Santosh Nepal ${ }^{1 *}$, Wolfgang-Albert Flügel ${ }^{2}$ and Arun Bhakta Shrestha ${ }^{1}$
}

\begin{abstract}
Understanding the upstream-downstream linkages in hydrological processes is essential for water resources planning in river basins. Although there are many studies of individual aspects of these processes in the Himalayan region, studies along the length of the basins are limited. This study summarizes the present state of knowledge about linkages in hydrological processes between upstream and downstream areas of river basins in the Himalayan region based on a literature review. The paper studies the linkages between the changes in the physical environment of upstream areas (land use, snow storage, and soil erosion) and of climate change on the downstream water availability, flood and dry season flow, and erosion and sedimentation. It is argued that these linkages are complex due to the extreme altitudinal range associated with the young and fragile geology, extreme seasonal and spatial variation in rainfall, and diversity of anthropogenic processes. Based on the findings, the paper concludes that integrated systems analysis is required to understand the holistic complexity of upstream-downstream linkages of hydrological processes in the river basin context. The integrated land and water resources management (ILWRM) approach can be instrumental in developing adaptive solutions to problems and can also enable stakeholders of upstream and downstream areas with various interests and needs to work together for the better utilization and management of land and water resources. As a part of this, the specific circumstances of the upstream communities, who live in fragile and inaccessible mountain areas with limited resource opportunities, should be taken into account so that incentive mechanisms can be established to encourage and acknowledge their contribution.
\end{abstract}

Keywords: Integrated land and water resources management; Himalayan region; Integrated systems analysis; Geoinformatics; Physical linkages; Value of environmental services

\section{Review}

Introduction

In a river basin, hydrological events that occur in the upper part may have a direct influence downstream (Nepal 2012), from a few to many hundreds of kilometers away. Understanding these upstream-downstream linkages is an essential basis for integrated land and water resources management (ILWRM) and planning in a river basin. It is particularly critical in basins with extreme elevation differences, where the climatic and geological conditions at the source of the river are completely different to those downstream, and in transoundary basins, where events in one country may directly impact the situation in another (Blaikie and Muldavin 2004; Rasul (2014);

\footnotetext{
* Correspondence: Santosh.Nepal@icimod.org

${ }^{1}$ International Centre for Integrated Mountain Development (ICIMOD), Kathmandu, Nepal

²Department of Geoinformatics, Hydrology and Modelling, Friedrich Schiller University, Jena (FSU-Jena), Germany
}

\section{勿

Shrestha et al. 2013). However, understanding such linkages is a challenge, and this is especially true in the Himalayan region (Nepal 2012), where a large, sparsely inhabited, poorly accessible, and widely glaciated area with fragile geology is the source of major rivers whose downstream basin areas are home to around one-fifth of the world's population (Eriksson et al. 2009; Ives and Messerli 1989).

Upstream-downstream linkages include environmental, socioeconomic, institutional, and cultural factors. Upstream impacts on hydrological processes can be broadly divided into two types: (i) human-influenced activities related to land use and (ii) natural impacts related to climate (Nepal 2012). Various studies have looked at impacts of land use change and potential impacts of climate on hydrological regimes (Chang and Franczyk 2008; Chang 2004; Ives and Messerli 1989; Eriksson et al. 2009; Sangjun et al. 2009; Thanapakpawin et al. 2007; 
Tiwari 2000; Wasson et al. 2008) and the influence on downstream water availability (Akhtar et al. 2008; Barnett et al. 2005; Eriksson et al. 2009; Immerzeel et al. 2010; Singh and Kumar 1997), but in general, they have only looked at individual aspects of the process.

Resource management practices in upstream areas can have both beneficial and adverse effects on downstream communities. Good catchment management practices upstream can provide better opportunities for downstream communities, for example, a clean and sustainable water supply for irrigation. In contrast, poor catchment management practices may not only degrade upstream environmental conditions, but will also limit the opportunities downstream. Hence, users in downstream areas often have great concerns about upstream land use and water management practices (Flügel and Bartosch 2011; Nepal and Adiga 2007). There is a general consensus that these issues are best addressed using an ILWRM approach, which promotes the coordinated development and management of water, land, and related resources (GWP 2000; Calder 2005). ILWRM provides a basis for developing cooperation between the upstream and downstream interests, including systems to compensate upstream users for actions to benefit downstream communities. In this context, the application of alternative dispute resolution (ADR) for conflict resolution, as suggested by Heathcote et al. (1998), is very useful. The question of scale is very important when looking at aspects of ILWRM. In this paper, the term 'catchment' is used to refer to micro to mesoscale catchments $(<100$ to $<10,000 \mathrm{~km}^{2}$ ), and the term 'river basin' to macro scale catchments, with basin areas more than $10,000 \mathrm{~km}^{2}$. In a small catchment, ILWRM can be based on local knowledge of interactions within the catchment, but at the larger basin level, it requires an understanding of the extended upstream-downstream linkages. This understanding supports evidence-based decision making by providing a basis for cost-benefit analyses and thus a starting point for planning and negotiations.

This review focuses on synthesizing the available information on upstream-downstream linkages related to hydrological processes in the Himalayan region; in particular, the impacts of climate and land use changes on water quantity and sediment transport. Specific information for the Himalayan region is limited; thus, relevant information drawn from research in other regions has also been included. Published peer-reviewed articles and technical reports on upstream-downstream linkages, impact of land use and climate change on water resources, and cooperation modalities between upstream and downstream communities were selected for the review. Anthropogenic effects, such as construction of infrastructure, dams, and hydropower, and water extraction and pollution, also have an impact on upstream-downstream linkages in a river basin at different scales. Especially upstream, storage may have multiple purposes (such as flood control, irrigation, and domestic water supply) which can influence the downstream flow in many ways (including timing and frequency), with reservoir management often having to prioritize conflicting purposes. Although this issue is important, the anthropogenic aspects of upstream downstream linkages were beyond the scope of this study. Specifically, the paper focuses on reviewing evidence related to the following questions: Does change in forest cover affect hydrological flows downstream? Do forest cover and vegetation affect soil erosion and sedimentation flows? What role does upstream vegetation play in controlling downstream floods? Will climate change impact river flows and related water availability in downstream areas?

Based on the results of the literature review, the paper considers the implications for cooperation between the upstream and downstream communities, and proposes a framework based on an ILWRM approach.

\section{The Himalayan region}

The Himalayan region lies at the junction between the Indian subcontinent and Asia, and contains one of the youngest, most dynamic and fragile mountain systems in the world, with geotectonic dynamics still ongoing. The system of mountain ranges extends $3,500 \mathrm{~km}$ from Afghanistan in the west to Myanmar in the east and is sometimes referred to as the Hindu Kush Himalayan $(\mathrm{HKH})$ region or extended Himalayan region to reflect the areas beyond the main Himalayan range (Figure 1). The region contains the world's highest mountains and is the source of ten large Asian river systems (Eriksson et al. 2009; Sharma 1997; Singh et al. 2000). The river basins provide a source of water for drinking, irrigation, hydropower, and industry, for a population of 1.3 billion people (Eriksson et al. 2009). The intensity, timing, and magnitude of the monsoon precipitation vary from east to west, with the longest duration of monsoon and greatest amounts of precipitation in the east. In the eastern part of the region, more than three-quarters of all precipitation falls during the summer monsoon months from June to September (Nepal 2012), whereas the western area receives more than one-third of total precipitation in winter (Shrestha 2008). The intense precipitation in the summer season, associated with the steep slopes and fragile geological conditions in the mountains, lead to floods and other water-related disasters like landslides that claim lives and damage property and infrastructure every year.

Although events in the Himalayas have an influence far beyond the mountains, the region is data poor, and there is a marked lack of data and information especially for the high mountain areas (Eriksson et al. 2009; Nepal 2012). 


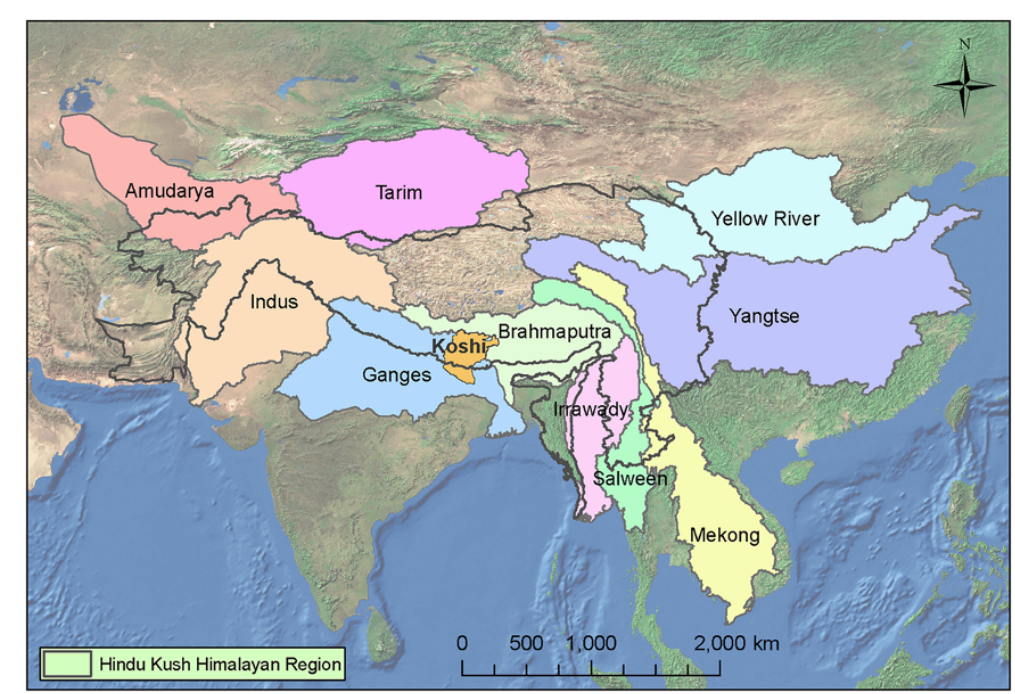

Figure 1 The Hindu Kush-Himalayan (HKH) region and position of the Koshi river basin. The region contains the headwaters of ten river basins; the Koshi basin lies within the Ganges basin (Source: International Centre for Integrated Mountain Development; the boundary of the Koshi basin is taken from ICIMOD's Koshi Basin Programme).

There are few detailed measurements of glacial ice, and the extremely poor accessibility and sparse population mean that the density of hydrometeorological stations of any sort is very low and far from being representative in a region characterized by high spatial variability of precipitation and temperature. This further compounds the problems of understanding the upstream-downstream linkages within the river basins.

\section{River zones}

In order to analyze and understand upstream-downstream linkages, river systems are broadly categorized into three distinct zones: source (or headwaters) zone, transition (or transfer) zone, and floodplain (or depositional) zone (FISRWG 1998; Miller and Spoolman 2012). Figure 2 shows a conceptual longitudinal profile of a river flowing from the Himalayan mountains to the sea depicting the three main zones in profile. In the Himalayan region, the source zone (or headwaters) comprises the high mountains with areas of glaciers, permafrost, and snow, very steep gradients with high ridges and deep valleys, and in the highest parts, little or no vegetation. The rivers originate in this zone within a channel network (Gomi et al. 2002). Relatively high soil erosion occurs from the steep slopes, and the resultant

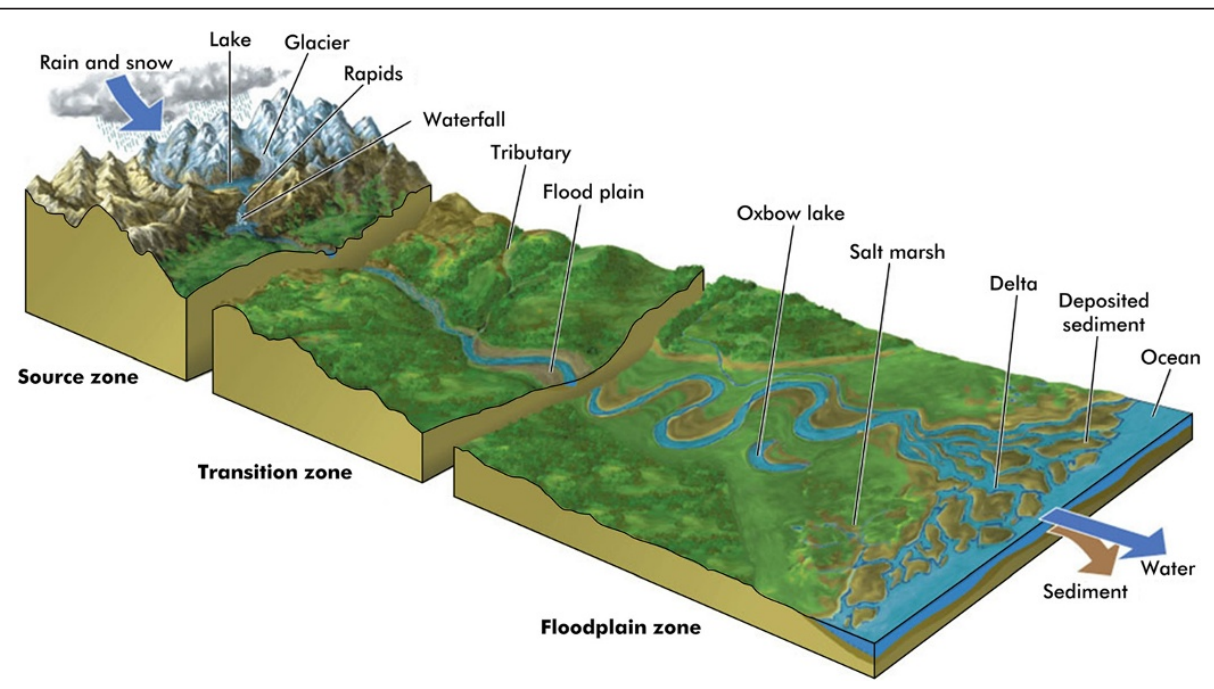

Figure 2 A schematic diagram of a river corridor showing three zones and their upstream downstream relationships. (Source: Miller and Spoolman 2012). From Miller. Living in the Environment, 17E. ๔ 2012 Brooks/Cole, a part of Cengage Learning, Inc. Reproduced by permission. www.cengage.com/permissions. 
sediment is transported downstream. The transition (or transfer) zone comprises the lower mountains and hills and also has steep slopes but with mixed vegetation. Human activities such as agriculture are prevalent. The floodplain zone begins when the river leaves the hills. The river starts to meander as a result of the low gradient and the sediment transported from the upstream areas is deposited as the river passes through the floodplain. At its mouth, the river may be divided into many channels flowing through a delta made of river-borne sediments into the sea. As the river flows from the headwaters to the floodplain, the river gains and loses water, but usually the river width and stream flow gradually increase. The headwater systems are important for understanding and protecting downstream ecosystems because they are intimately linked (Gomi et al. 2002). However, because the headwater streams are small and numerous, their roles are typically underestimated and they are poorly managed compared to the larger downstream systems. Some processes such as glacier melt are limited to the headwater zone. Erosion, transfer, and deposition occur in all zones to some extent (FISRWG 1998), but the dominant processes generally change from erosion upstream to deposition downstream. The terms 'upstream' and 'downstream' are also relative, for example the transition zone is downstream in relation to the headwaters but upstream in relation to the flood plains. Thus, upstream and downstream relationships occur at different locations and scales, and the magnitude and nature of problems and related effects change between the local micro catchment scale and the regional macro river basin scale (Nepal 2012).

\section{Upstream-downstream linkages in the Himalayan region}

Physical linkages consist of numerous activities and processes that occur in upstream areas in connection with the physical environment (such as land use change, runoff generation, and snow and glacier melting) and their impacts on the downstream environment. There are many processes which occur simultaneously at different spatial and temporal scales and these are, by nature, complex. Figure 3 summarizes some of the major conceptual linkages schematically. Changes in the status of the natural environment (for example in climatic conditions) and human systems (for example resource management practices) may have both qualitative and quantitative impacts on the overall hydrological regime. The current status of knowledge on the upstream-downstream linkages related to hydrology is summarized in the following; the major topics and papers reviewed are listed in Table 1.

\section{Impact of land use change on the hydrological regime}

One of the major aspects of upstream-downstream linkages in terms of water is the relationship between upstream changes in land use and land cover and downstream water availability. Land use change and its impact on different aspects of the environment has been studied from both a global (Watson and Verardo 2000) and regional or local perspective (Awasthi et al. 2002; Calder et al. 1995). Land use management practices can have both positive and negative impacts on water quantity (water availability, groundwater recharge, and runoff), and water quality (soil erosion, sedimentation, pollution) (DeFries and Eshleman 2004). These processes and associated attributes indicate important relationships between upstream and downstream areas and developing a better understanding of the interaction between land use change and hydrological processes is a major concern in the context of sustainable water resources management (DeFries and Eshleman 2004).

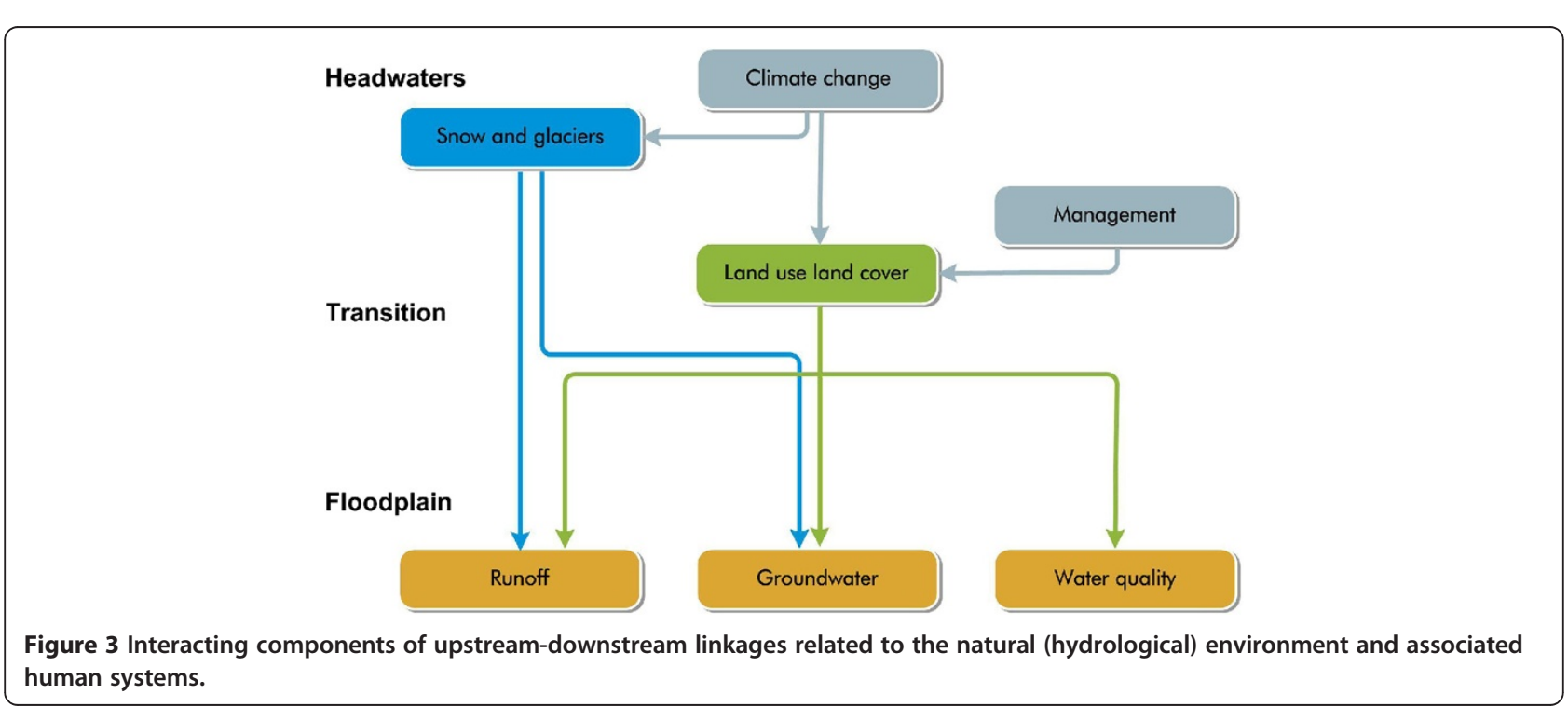


Table 1 Summary of major topics and literature reviewed

\begin{tabular}{|c|c|c|}
\hline Type of linkage & Focus of studies & Sources \\
\hline \multirow{3}{*}{$\begin{array}{l}\text { Impact of land use change on } \\
\text { the hydrological regime }\end{array}$} & General & DeFries and Eshleman (2004); Bronstert et al. (2002) \\
\hline & $\begin{array}{l}\text { Impact of forest cover on } \\
\text { stream flow and floods }\end{array}$ & $\begin{array}{l}\text { Douglass and Swank (1975); Hamilton and King (1983); Hibbert (1967); } \\
\text { Bosch and Hewlett (1982); Andreaassian (2004); Bosch and Hewlett (1982); } \\
\text { Herron et al. (2002); Zhang et al. (1999); FAO, CIFOR (2005); Ives (2004); } \\
\text { Bruijnzeel (1990); Brooks et al. (1991); Gilmour et al. (1987); Hamilton and } \\
\text { Pearce (1987); Beven (2001); Bruijnzeel and Bremmer (1989); Bruijnzeel (2004) }\end{array}$ \\
\hline & $\begin{array}{l}\text { Impacts in large-scale } \\
\text { catchments }\end{array}$ & Costa et al. (2003); Krause (2002); Siriwardena et al. (2006) \\
\hline \multirow[t]{2}{*}{$\begin{array}{l}\text { Impact of land use change on } \\
\text { soil erosion and sedimentation }\end{array}$} & $\begin{array}{l}\text { Role of vegetation cover and } \\
\text { land use in reducing erosion }\end{array}$ & $\begin{array}{l}\text { Stocking (1984); Walling (1999); (Gardner and Gerrard 2003); Tang Ya } \\
\text { and Nakarmi (2004);; Shrestha (1997); Morgan et al. (1984); Impat (1981); } \\
\text { Ramsay (1987) }\end{array}$ \\
\hline & River sediment load & $\begin{array}{l}\text { Bruijnzeel and Bremmer (1989); Sharma (1997); Laban (1979), cited in } \\
\text { Tiwari (2000); Alford (1992); Mool et al. (2001); Sharma (1997); Milliman } \\
\text { and Meade (1983); Ives and Messerli (1989); Kiersch (2000); Bruijnzeel } \\
\text { (1990); (Wasson (2003); Wasson et al. (2008) }\end{array}$ \\
\hline \multirow{4}{*}{$\begin{array}{l}\text { Impact of climate change on the } \\
\text { hydrological regime }\end{array}$} & Temperature & Shrestha et al. (1999); Nepal (2012); Liu and Chen (2000); IPCC (2007); \\
\hline & Precipitation & Shrestha et al. (2000); Nepal (2012); Singh et al. (2011); \\
\hline & Cryosphere & $\begin{array}{l}\text { Schneeberger et al. (2003); Bajracharya \& Shrestha (2011); } \\
\text { Kundzewicz et al. (2007); Eriksson et al. (2009); Immerzeel et al. (2012); }\end{array}$ \\
\hline & River flow & $\begin{array}{l}\text { Rees and Collins (2006); Nepal et al. (2014); Singh and Jain (2006); } \\
\text { Nepal (2012); Immerzeel et al. (2012); Singh and Bengtsson (2004, 2005); } \\
\text { Lutz et al. (2014); Immerzeel et al. (2010) }\end{array}$ \\
\hline
\end{tabular}

The potential impact of land use change on different hydrological processes has been summarized by Bronstert et al. (2002); the main processes are shown in Table 2. Forests generally influence local hydrology through evapotranspiration. They also affect infiltration processes into underlying soil and ground cover through their root systems and organic humus layer, which contributes to controlling erosion dynamics. The local climate also influences the processes by which forest and land use affect the hydrological cycle (Hibbert 1967; Wilk 2002).

The impact of land use change on average stream flow has also been investigated. Most research on forest removal in catchments has confirmed an increase in stream flow volume (Douglass and Swank 1975; Hamilton and King 1983; Hibbert 1967; Ives and Messerli 1989). Hibbert (1967) investigated the effects of altering forest cover on water yield in 39 catchments worldwide. The results suggested that forest reduction increases water yield, and reforestation decreases water yield. Bosch and Hewlett (1982) extended Hibbert's work and reviewed land use changes in an additional 55 catchments, with similar results. Several more recent studies have also indicated that a reduction in forest cover can increase water yield (Andreaassian 2004, Bosch and Hewlett 1982; Herron et al. 2002), interpreted mainly as the result of reduced evapotranspiration from the reduced forest cover (Zhang et al. 1999).

The relationship between land use change and peak flow is also much discussed. Contrary to popular belief, upstream forests have been shown to have only a limited influence on major downstream flooding, especially large-scale events (FAO, CIFOR 2005; Ives 2004). However, peak flows (or floods) can be affected by change in land use and land cover, especially when the infiltration capacity of the soil is reduced. This can occur through soil compaction or erosion, or increase in drainage capacity (Bruijnzeel 1990). As the amount of precipitation increases, the influence of soil and plant cover on stream flow generation diminishes (Brooks et al. 1991; Bruijnzeel 1990) due to the saturated soil conditions. The impact of land use on peak flow generation is less visible in a large basin because of the time-lag difference between the different tributaries and spatial and temporal variations in rainfall and land use. Although this phenomenon may reduce the effect of land use change on peak discharge in a large river basin, a sub-watershed (or micro catchment) may experience overall increase in peak stream flow as a result of changes in land use (Brooks et al. 1991; Bruijnzeel 1990; FAO, CIFOR 2005).

Gilmour et al. (1987) studied the effects of forestation on soil hydraulic properties in the mid hills of Nepal. The study indicated that forestation of heavily grazed grasslands can lead to significant increases in surface soil infiltration capacity. The author further suggested that the measured data refute the contention that deforestation necessarily results in an increase in large-scale flooding and conversely that forestation would decrease the frequency or magnitude of such flooding. The infiltration rate is highly dependent on the antecedent soil moisture condition. Flooding generally arises as a result of intense 
Table 2 Potential impacts of land use changes and relevance for components of hydrological cycle

\begin{tabular}{|c|c|}
\hline Processes & Potential impact of land use change \\
\hline Interception storage & $\begin{array}{l}\text { Greatly affected by vegetation changes (e.g. crop harvest, forest cutting); } \\
\text { relevant for evapotranspiration/energy balance }\end{array}$ \\
\hline Litter storage & $\begin{array}{l}\text { Affected by vegetation changes, in particular forest cutting; relevant for } \\
\text { evapotranspiration/energy balance }\end{array}$ \\
\hline Root zone storage & $\begin{array}{l}\text { Affected by management practices like tilling methods, relevant for } \\
\text { evapotranspiration and storm runoff generation }\end{array}$ \\
\hline Infiltration - excess overland flow & $\begin{array}{l}\text { Affected by crop cultivation and management practices; relevant for } \\
\text { storm runoff generation in the case of high rainfall intensities and low } \\
\text { soil conductivity; may be enhanced by soil siltation and crusting }\end{array}$ \\
\hline Saturation - excess overland flow & $\begin{array}{l}\text { Only slightly affected by land use changes (process is controlled by } \\
\text { topography and subsurface conditions) }\end{array}$ \\
\hline Subsurface stormflow & $\begin{array}{l}\text { Only slightly affected by land use changes (process is controlled by } \\
\text { topography and subsurface conditions) }\end{array}$ \\
\hline Runoff from urbanized areas & $\begin{array}{l}\text { Highly affected by sewer system and sewage retention measures; } \\
\text { relevant for storm runoff from urban areas }\end{array}$ \\
\hline Decentralized retention in the landscape & $\begin{array}{l}\text { Affected by landscape structuring and agricultural rationalization of } \\
\text { arable land; relevant for storm runoff concentration from arable land }\end{array}$ \\
\hline
\end{tabular}

rainfall over a short period of time during the monsoon season, especially when the soil is already saturated and most of the rainfall is drained as runoff. Even where forest cover is very good, such flood events remain likely. Hamilton and Pearce (1987) also concluded that reforestation might not prevent flooding to any great extent in the lower reaches of major rivers, or significantly reduce flooding during major storm events.

The impact of land use change on baseflow depends on the infiltration capacity of land cover and evapotranspiration by plants. Most experimental evidence in rainfall-dominated regimes suggests that forest removal (or change from high-water-use plants to low-water-use plants) increases dry season flows (Brooks et al. 1991). In contrast, dry season flows from deforested land may decrease if the soil infiltration capacity is reduced during the rainy season to the extent that groundwater reserves are insufficiently replenished (e.g. through use of heavy machines during forest harvesting or subsequent agriculture, an increase in impervious areas such as roads and buildings, or loss of topsoil) (Beven 2001; Bruijnzeel and Bremmer 1989; Bruijnzeel 1990). If, on the other hand, soil-surface characteristics are maintained sufficiently after clearing to allow the continued infiltration of rainfall, the reduced evapotranspiration associated with forest removal will appear as increased dry-season flow (Bruijnzeel 2004). Bruijnzeel and Bremmer (1989) suggested that the important factor is whether reforestation of degraded lands in the Himalayas would eventually lead to the improved infiltration conditions required to recharge the groundwater supply and improve dry season flow. Bruijnzeel (1990) cautioned that more rigorous work is required to obtain firm answers on the relationship between reforestation and dry season flows.
The impact of land use change on hydrology is highly scale dependent. The majority of observation-based studies are experiments in small-scale catchments (Bosch and Hewlett 1982; Hibbert 1967). Results in large-scale catchments, suggest similar effects to those in small-scale catchments, with deforestation resulting in an increase in streamflow (Costa et al. 2003; Siriwardena et al. 2006). Hydrological models are also widely used to assess scenarios of land use (Bronstert et al. 2002; Krause 2002; Pauleit et al. 2005; Siriwardena et al. 2006). In general, studies related to the role of vegetation on the hydrological regime indicate that the impact is more evident in small catchments than in large river basins. Forest has a very limited influence on major flood events, particularly in the monsoon-dominated Himalayan region; the addition of a large volume of water over a short period of time reduces the infiltration capacity of the soil and thus vegetation (deforestation/afforestation) plays a relatively minor role.

\section{Impact of land use change on soil erosion and sedimentation}

The role of vegetation cover in reducing soil erosion in the headwater areas and transition zone, and thereby reducing sediment load in flood plain areas, is widely discussed. Stocking (1984) suggested that lack of vegetation cover accelerates erosion, and Walling (1999) noted that a change in surface condition from natural undisturbed land to cultivation will in general result in an increase in the soil erosion rate. The impact of land use change on rates of soil loss, and in particular the impact of land clearance (i.e., removal of trees and vegetation) and cultivation on erosion rates, have been extensively documented. Results obtained from erosion plots and catchment experiments 
provide clear evidence of the sensitivity of erosion rates with regard to changing land use and related management (Walling 1999).

Gardner and Gerrard (2003) studied the runoff and soil erosion on cultivated rain-fed terraces in the Likhu Khola catchment in the mid hills of Nepal; the soil loss by erosion was reported to be between 2.7 and $12.9 \mathrm{t} / \mathrm{ha}$. A comparison of soil loss from 'farmers' practice' control plots, also in the mid hills of Nepal, showed a wider variation between 2.8 and $131.6 \mathrm{t} / \mathrm{ha}$ from the same plot in different years, with an average of 39.4 $\mathrm{t} / \mathrm{ha}$, indicating the importance of timing (in terms of crop growth and ground cover) and intensity of localized rainfall events (Ya and Nakarmi 2004). A study by Shrestha (1997) in the mid hills of Nepal estimated annual soil loss rates based on the soil erosion assessment model from Morgan et al. (1984). The rate was highest (up to $56 \mathrm{t} / \mathrm{ha}$ ) in areas with rainfed cultivation, which is directly related to the sloping nature of the terraces, and comparatively lower (less than $10 \mathrm{t} / \mathrm{ha}$ ) among land use types such as forest, grazing land, and rice cultivation. The lowest soil losses (less than $1 \mathrm{t} / \mathrm{ha}$ ) were recorded in dense forest. Similarly, Impat (1981) and Ramsay (1987) summarized the literature on measured rates of surface erosion in Nepalese mountains and found high rates of surface erosion under various circumstances with considerable differences between land use types, e.g., overgrazed pasture $(9.85 \mathrm{t} / \mathrm{ha})$, protected pasture $(1 \mathrm{t} / \mathrm{ha})$, and forest $(0.43 \mathrm{t} / \mathrm{ha})$. Most of these studies reflect the condition and processes in the small-scale catchments in the transition zone of the region's rivers. In general, the studies indicate that the higher the density of vegetation on the hill slopes, the lower the erosion rate, and vice versa.

Estimating the sediment load in the Himalayan river basins is very challenging. Bruijnzeel and Bremmer (1989) suggest that the sediment loads from large river basins cannot be estimated accurately because of the wide range of erodible materials contributing sediment and the different methods used for estimation in different studies. Sharma (1997) indicated that nearly 135 million tons per year ( $t$ /year) of sediment is transported from the Koshi (sometimes written Kosi) river basin (about $57,000 \mathrm{~km}^{2}$ ), into the Ganges river. Laban (1979) cited in Tiwari (2000), reported a sediment load of about 119 million t/year in the same river, equivalent to $2-\mathrm{mm}$ topsoil depth over the entire catchment. The specific sediment yield was reported to be around 2,500 $\mathrm{t} / \mathrm{km}^{2} /$ year (equivalent to $25 \mathrm{t} / \mathrm{ha}$ ), which is very high compared to both the Ganges itself (491 t/ $/ \mathrm{km}^{2} /$ year) and other river systems in the world (for example, Brahmaputra 578, Amazon 207, and Nile $40 \mathrm{t} / \mathrm{km}^{2} /$ year) (Alford 1992; Mool et al. 2001; Sharma 1997). Even when the different size of the basin areas is taken into account, the sediment loads of the Himalayan rivers (Yellow, Ganges/Brahmaputra,
Yangtze) are high compared to those in other parts of the world (Milliman and Meade 1983). Among these, the Koshi river basin has an exceptionally high sedimentcarrying capacity; although, it comprises only $5 \%$ of the Ganges river basin area, it contributes nearly $25 \%$ of the total sediment load (Sharma 1997).

The sediments eroded from the upstream are deposited on the river bed and in the flood plains downstream. Downstream sediment yield is a complex function of upstream erosion process and transport, and deposition and remobilization processes in the transition zone, and is not always the direct result of upstream land use practices. Natural erosion in the Himalayas has been shown to be an important phenomenon and is probably higher than in most other mountain systems in the world (Ives and Messerli 1989). This is primarily due to the monsoon climate which includes high intensity precipitation concentrated within a short period of time associated with high topographic gradient and a young and fragile mountain system. Human impacts on sediment yield may be substantial in regions with stable geological conditions and low natural erosion rates. However, in regions with high rainfall rates, steep terrain, and high natural erosion rates (as in the Himalayan region), the relative impact of land use may be low (Kiersch 2000). According to Bruijnzeel (1990), it is the combination of several factors that leads to the high rate of sediment transport in the Himalayan river basins, including intense rainfall and resulting high stream flow rates, and steep terrain and fragile geology with relatively low opportunities for storing the eroded material. Wasson (2003) and Wasson et al. (2008) suggested that the relationship between land use and sedimentation in the Himalayan region is not clear, and that it is difficult to identify the role of human activities in the erosion and sediment transport system, despite many decades of research.

\section{Impact of climate change on the hydrological regime}

It is important to understand how the hydrological system in the Himalayan region is likely to respond to future changes in climate, the differences in impact in the headwaters, transition, and plain zones, and the implications for water availability. The direct impact of changes in precipitation (including seasonal variations and intensity) are likely to be important for long-term water availability as well as for extreme events such as floods and flash floods, but indirect impacts on the cryosphere, evapotranspiration, and other factors may be equally significant. A number of authors have developed projections of future climate in the region and potential impacts on hydrology. Despite the inherent uncertainty, they provide a guide to possible future impacts under different climate scenarios.

Many studies have indicated that there is already a widespread warming trend in the Himalayan region. 
According to Shrestha et al. (1999), the annual maximum temperature in Nepal increased at an average rate of $0.06^{\circ} \mathrm{C} /$ year between 1974 and 1994 , and similar results have been reported by others both in Nepal (Nepal 2012) and on the Tibetan Plateau (Liu and Chen 2000). The projected temperature scenarios based on general circulation models (GCMs) and regional climate models (RCMs) suggest an increase in annual average temperature by the end of the century for South and East Asia of about $3.3^{\circ} \mathrm{C}$, which is significantly above the global mean of about $2^{\circ} \mathrm{C}$ (Christensen et al. 2007).

In contrast, no clear trends have been observed in precipitation over the past 40 years or so (Nepal 2012; Shrestha et al. 2000). Similarly, projections for future precipitation in the region are not consistent, although many models predict slightly increased precipitation overall, with an increase in summer and decrease in winter and accelerated hydrological cycle (Singh et al. 2011). There is some consensus that the main changes will be reflected in an increase in variability of precipitation, with more intense rainfall events and low or no rainfall days and changes in the overall patterns and timing of annual distribution (Goswami et al. 2006; IPCC 2007; Dobler et al. 2011).

In the headwater zone, climate change is likely to have an impact on the cryosphere (snow, glaciers, and permafrost). Glacier melt contributes only moderately to annual river discharge in the monsoon-dominated eastern and central parts of the Himalayas, accounting on average for $10 \%$ of the river flow of the Ganges and between 2\% to $20 \%$ of the other rivers (Miller and Rees 2011). However, the glacier melt is an important source of water for both agriculture and vegetation in the upper reaches, especially during the dry season (Nepal et al. 2014). In contrast, in the tributaries of the Indus basin in the western Himalayas, where the summer monsoon is weak and the winter monsoon is very active, glacial and snow melt contribute close to $60 \%$ of water discharge (Singh and Jain 2006). There is increasing evidence that the glaciers in the region are receding. The projected rise in temperature is expected to lead to a further increase in glacier melting, with an increase in flows in the shorter term, but a gradual decrease thereafter as glacial area and volume diminish (Eriksson et al. 2009; Kundzewicz et al. 2007). Immerzeel et al. (2012) estimated the response of glaciers in the Langtang catchment (central Nepal) under various climate scenarios and reported that glacier runoff remained relatively constant until 2040, decreasing thereafter. The initial increase will coincide with the time of most intense rainfall in the summer.

Changes in snowfall, and thus in snowmelt runoff, may be more marked in the short term than changes from glacier melt. Snowmelt runoff in Dudh Koshi catchment in eastern Nepal was projected to decrease by $30 \%$ to $60 \%$ with a $2^{\circ} \mathrm{C}$ to $4^{\circ} \mathrm{C}$ rise in temperature, with the river shifting from a 'melt-dominated' to a 'rain-dominated' river (Nepal et al. 2014). Changes in snowmelt might be more marked in the western parts of the region where there is more winter precipitation. In a study that compared the drier, western Himalayas with the monsoon-dominated, eastern part, Rees and Collins (2006) suggested that climate warming would not have a uniform effect on river flow in the region.

In the transition zone, with its primarily rainfed agriculture, the major impacts of climate change in terms of the hydrological regime are likely to result from the increased variation in precipitation. This includes the projected seasonal changes in rainfall, with less during the dry season and more in the rainy season. An increase in extreme rainfall events may also lead to an increase in flash floods of the sort that occurred in the mid hills of Nepal in 1993 (Thapa 2001), which led to debris flows, landslides, and flooding, with considerable loss of life, and damage to agricultural land, irrigation projects, highways, bridges, and hydropower projects, including massive siltation of the Kulekhani reservoir, in the western part of the Koshi river basin.

In terms of hydrology, the plains areas are most strongly affected by changes in water availability from river flow. Overall discharge from the upper catchment is affected by a combination of runoff from glacier melt, changes in total precipitation, changes in the form of precipitation from snow to rain, seasonal changes in precipitation, and changes in net runoff. A study of the Langtang valley in the central Himalayas in Nepal showed that even though the runoff from glacier melt is projected to decrease by the end of the century, total discharge is projected to increase as the loss of flow is compensated by an increase in rainfall and base flow (Immerzeel et al. 2012). But this increase will be mainly during the rainy season, and could result in more frequent flood events of higher magnitude (Hassan et al. 2014). The projected increases in rainfall might compensate for the reduction in the contribution of meltwater from glacial shrinkage even in the Indus (Immerzeel et al. 2013). Recently, an analysis of the hydrological impact of climate change was conducted using the latest climate model outputs for a large spatial domain covering the upstream parts of the Indus, Ganges, Brahmaputra, Salween, and Mekong river basins (Lutz et al. 2014). The study used a spatial resolution of $90 \mathrm{~m}$, compared to $1 \mathrm{~km}$ in the study by Immerzeel et al. (2013), and future glacier change was parameterized, whereas in the Immerzeel study glacier dynamics were explicitly included. Despite the conceptual differences of the two studies, the conclusions are remarkably similar: the average annual runoff will increase or remain stable in the decades up to 2050 as a result of projected increases in 
precipitation in combination with sustained higher glacier melt.

It is argued that climate change may have a greater impact on seasonal water supplies than on annual water supplies, as shown, for example, in studies of the Sutlej river basin (Singh and Bengtsson 2004; Singh and Bengtsson 2005). Water supplies will also be affected by the projected increase in evapotranspiration resulting from the increase in temperature and reduction in winter season precipitation ( $\mathrm{Mu}$ et al. 2013) leading to reduced runoff, increased abstraction of water for irrigation, and thus reduced flow.

\section{Discussion}

The research shows that a complex relationship exists between upstream activities and processes and their influence on the downstream areas. The upstreamdownstream relationships have multiple facets, which also reflect the complex relationships between the natural environment and the people who live within it. The level of human-environment complexity is especially high in the Himalayan region as a result of the specific mountain characteristics of inaccessibility, fragility, marginality, and diversity (Jodha 2002). The major conclusions of the literature review, and the implications for planning, can be summarized as follows:

\section{Hydrology and erosion}

Reduction in forest cover results in higher stream flow on average due to the reduction in evapotranspiration following loss of vegetated areas and lower soil infiltration. However, reduced forest cover is also likely to result in an increase in overland flow and reduction in baseflow if the soil becomes compacted or removed, which could result in a reduction in water availability in the longer term. Although forested land has a higher soil infiltration capacity, this has less impact on runoff rates during intense rainfall, especially when the soil is already saturated. Vegetation has a greater effect on the hydrological regime in small basins than in large river basins, and the impact of forest soil in reducing runoff is only observable at a local scale. Overall, forest cover has only a limited influence on major flood events in the monsoon-dominated Himalayas, although it may influence smaller and more localized events.

Vegetation cover hinders erosion by reducing the impact of rain drops and stabilizing soil particles in the root zone; densely forested land has the lowest erosion rates. In small-scale catchments, land clearance and cultivation are seen to lead to an increase in soil erosion rates, especially on sloping land. Land use practices that leave soil exposed at times of heavy rainfall are particularly sensitive. However, soil erosion rates are naturally high in the Himalayas as a result of the steep slopes, fragile geological formations, and high intensity rainfall; thus, on a larger scale, the role of land use and land cover change can be dwarfed by natural soil erosion, particularly during mass wastage. At the same time, vegetation reduces natural erosion and landslides, especially on sloping land. The overall role of human activities in the erosion and sediment transport system in the Himalayas remains not fully understood and requires additional research.

The role of forest and other vegetation in, and the impacts of deforestation and cultivation on, runoff, base flow, and soil erosion are complex, and it is important not to draw conclusions from results focused on individual aspects of the process. Although sectorial studies at one scale might indicate benefits from certain actions, the same actions might be seen as profoundly detrimental from a different perspective. For example, afforestation upstream may lead to a decrease in average water availability downstream. But this is not a rationale for reducing reforestation, or cutting down forest. The benefit in the short-term of an increase in water availability is likely to be outweighed by the medium-term loss of soil water storage capacity (in the unsaturated zone) due to the high erosion rate of exposed soil surface, and potential longer term loss of the entire soil profile. This would result in a reduction of infiltration, a decrease in the more important dry season base flow, and a change from a perennial river to a seasonal or ephemeral river. Forests, and thus reforestation, provide many benefits including reduction of soil erosion, maintenance of soil fertility, better environment for infiltration, biodiversity conservation, and essential ecosystem services including climate regulation, which could have co-benefits for both upstream and downstream communities and in the region as a whole (Bruijnzeel and Bremmer 1989). All such factors must be considered when analyzing the impact of forest increase, maintenance, or reduction.

One of the major impacts downstream is deposition of sediment. But erosion and deposition are extremely complex processes, and the topic serves mainly to illustrate the complexity of upstream-downstream linkages. The finest sediment, silt, is generally beneficial and is the source of the high fertility of the alluvial plains. Preventing conveyance and deposition of silt will have a negative impact on soil fertility in the plains. Equally, large deposits of coarse sediment brought down in flood conditions can completely cover previously fertile land (ICIMOD 2009), and preventing this would be positive. Because of the high sediment load, the main channel of the Koshi river in eastern Nepal shifted westward by about $115 \mathrm{~km}$ over more than 220 years (Gole and Chitale 1966; Thakur and Tamrakar 2001). Further movement was halted by construction of a barrage and embankment system at the start of the plains area to control flooding and 
provide irrigation water. In 2008, a major breach of the embankment resulted in an avulsion of the river, which picked up an old channel $120 \mathrm{~km}$ to the east, resulting in large-scale inundation of several districts in Nepal and India and devastation of the affected area, affecting a population of 4.8 million (Dixit 2009). Such events serve to illustrate the close linkages between upstream interventions and downstream impacts, and highlight the need for cooperation between upstream and downstream areas within and between countries.

\section{Impacts of climate change}

The HKH region is likely to suffer significant changes in its hydrological regime as a result of global climate change. Rainfall patterns are projected to change, with an increase in precipitation in summer, and a decrease in winter, accompanied by an increase in no or low rainfall days and more heavy rainfall events. Temperatures are projected to rise, which will lead to increased glacier melting and loss of glacial storage capacity, resulting initially in higher contributions to flow, followed by a gradual decrease. Higher temperatures will also lead to a reduction in snowfall and a shift from delayed runoff from snowmelt, to direct runoff from rainfall. Changes in temperature will also affect evapotranspiration rates, and changes in precipitation patterns will affect soil water uptake capacity. Overall, total discharge is expected to increase, but this increase will take place mainly in summer when discharge is already high.

The changes associated with climate may severely affect water availability, agricultural production, and hydropower generation in downstream areas (Immerzeel et al. 2010), and thus have an impact on the livelihoods of a large number of people living in the transition and flood plain zones. Changes in the monsoon regime are likely to be particularly important as it is the predominant source of moisture, particularly in the eastern and central Himalayas. In the western part of the region, the changes in winter precipitation are likely to be more critical from the hydrological perspective. Indirect impacts, such as on glacier and firn field melting, snowfall, storage, and evapotranspiration, will also have an important impact. Understanding the role of meltwater is vital for the planning of many water resource development projects (such as hydropower, irrigation, and dams) (Schneeberger et al. 2003). The change in rainfall patterns can have a marked impact on the crop cycle. Drier winters, more dry days, and higher temperatures will increase the requirement for water for irrigation; a change in the timing of precipitation will affect the agricultural calendar and optimum planting times; and increased heavy rainfall events may lead to loss of topsoil, especially if they take place where vegetation cover is minimal, as well as an increased risk of flooding.

\section{Regional heterogeneity}

The upstream-downstream linkages in the Himalayas are complex, and it is not always possible to generalize understanding from one basin to another. Although there are many similarities, there are also many differences. For example, upstream water supply is critical to sustain reservoir systems, which store and release water to downstream areas when most needed. In the west of the region, the irrigation system of the Indus, which is the largest irrigation network in the world, is regulated through two major storage dams, both fed predominantly by meltwater (Immerzeel et al. 2010). In contrast, in the east, the irrigation systems that depend on the Ganges river are regulated by barrages, and the river is predominantly rainfed. Hydrology in the Ganges and Brahmaputra basins to the east is dominated by the summer monsoon, whereas the winter rains play a more important role in the Indus basin to the west.

With climate change, the wide variation in latitude, longitude, and topography across the extended Himalayas will influence the degree of warming, the extent of monsoon precipitation, and the impact on snowfall. The changes on the dry alpine Tibetan Plateau are likely to differ from the changes that will be experienced in the rugged mountain ranges to its south. Studies of present and projected future climate tend to be unevenly distributed, however, and may not capture this diversity. Little observational data are available for the sparsely inhabited Tibetan Plateau and high mountain regions. Most projections use data downscaled from global climate models, and regional applications are limited by the lack of high-resolution regional or local data, which may lead to inaccuracies, as both rainfall and temperature have a highly inhomogeneous distribution over relatively small distances. Immerzeel et al. (2010) emphasize that results for the region should be treated with caution because of difficulties associated with monsoon simulation and inter-annual variations in precipitation. The climate projection data should be taken as indicative and the uncertainty should be recognized in planning processes. The regional heterogeneity means that the impacts of climate and other change on water availability in downstream areas are likely to vary across the region, and this is another reason to encourage countries located in the upstream-downstream areas to develop close cooperation mechanisms to understand and address flood and drought events.

\section{The need for an integrated systems analysis approach}

The upstream-downstream linkages in the Himalayan region are part of a complex system; they are interdisciplinary and interdependent and cannot be understood from simple analysis of the individual components. In order to understand the nature and magnitude of the impacts, it is 
necessary to use an integrated systems analysis approach (Flügel 2000) based on a comprehensive understanding of the natural environment and the related human systems. The first step is to develop understanding of the hydrological dynamics at a catchment level. Understanding of the relationship of different watershed components (such as soil, vegetation, geology, snow and glaciers, and climate) to stream flow provides a basis for understanding the linkages between the upstream and downstream areas (Nepal 2012). This in turn provides the basis for integrated water resource management at a basin scale.

The main components of the integration process, from information gathering and processing using geoinformatics tools, to development of policies and governance approaches, are shown schematically in Figure 4 in the form of a framework for applied geoinformatics for integrated systems analysis (Flügel 2009; Flügel 2011) of river basins, for example, with respect to impacts from changing land use land cover (LULC) and climate. The river basin environment is subdivided into its natural environment (NE), comprising the physiographic basin features, and its human dimension (HD), representing the socioeconomic use and exploitation of its natural resources provided as ecosystem services (ESS). The efficiency of the management (M) of resource utilization and the way in which it is implemented within the existing governance structures, for example as ILWRM, controls the impacts on quantity and quality of the regenerative resources like surface and subsurface water bodies. In this regard, the term sustainability applies to management that accounts for resource regeneration capacity within the basin by means of ecosystem functions (ESF). Impacts and the degree of sustainability can be assessed and quantified by means of integrated systems analysis (ISA) applying geoinformatics tools and a process-based consistent regionalization approach, such as the response unit (RU) concept (Flügel 1995; Pfennig et al. 2009), that allows for scaling up and downscaling of process understanding. The results from the ISA are input to decision information support tools (DIST) that provide decision support (DS) by means of multi-criteria decision support systems (DSS). As a result, governance structures can be adapted to implement alternative resource management strategies to mitigate environment impacts identified by the ISA.

The details and scope of such a framework might be different in distinct ecological zones reflecting the unique dominant processes. Especially for hydrological system dynamics, distributed and process-oriented hydrological models offer powerful tools for understanding the process dynamics that control the distributed generation of runoff from the river basin landscape, and the associated generation of water resources (Beven 2001; Flügel 2011, Flügel 2009; Nepal et al. 2014). From the hydrological point of view, precipitation is the major driving factor and the flow of water in a river connects the upstream areas with the downstream. The traditional sectorial approach considers water management separately to the management of other natural resources such as forest and agriculture. However, the hydrology across

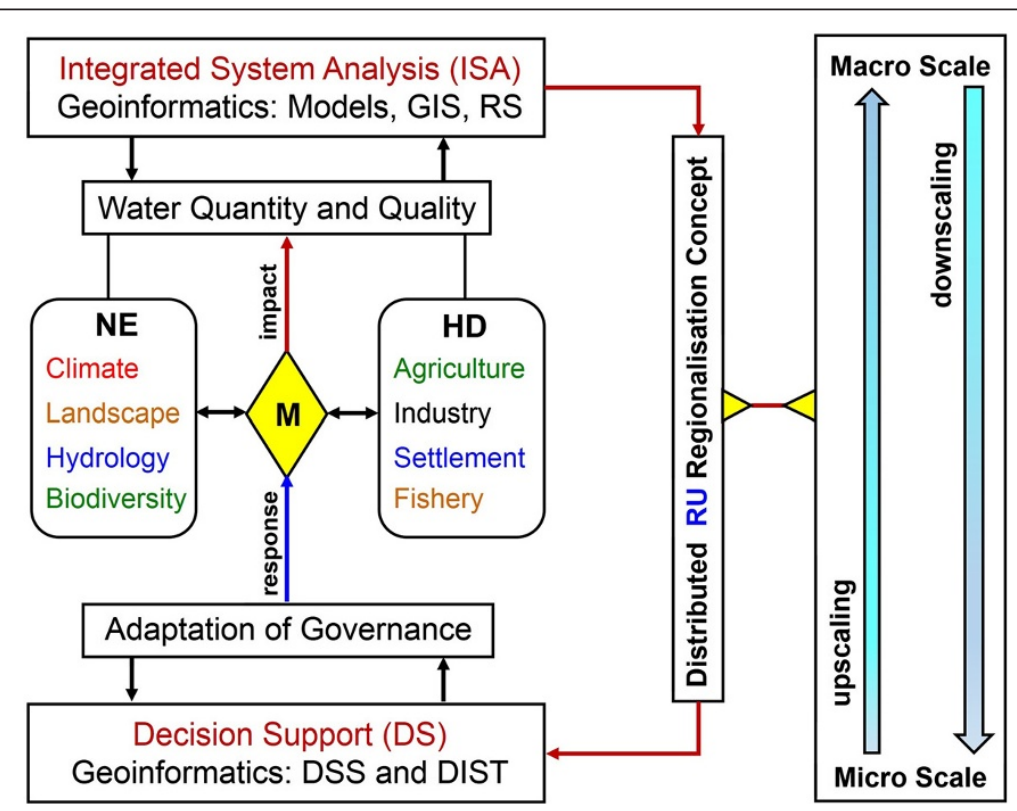

Figure 4 Applied geoinformatics for integrated systems analysis. Note: NE = natural environment; $M=$ management; $H D=$ human dimension; GIS = Geographic Information System; RS = remote sensing; RU = response unit; DSS = Decision Support System; DIST = Decision Information Support Tool. 
the river basin landscape is closely interlinked with the different components in upstream and downstream areas, and management strategies and interventions designed without taking these into account will be ineffective. Understanding of these linkages is essential for the planning and management of water resources (such as hydropower development and irrigation systems) (Flügel and Bartosch 2011). Eventually, this information will provide a basis for strengthening linkages between upstream and downstream communities in the context of sustainable management.

Hydrological processes occur at a wide range of scales, from unsaturated flow in a soil profile to floods in river systems of a million square kilometers (Blöschl and Sivapalan 1995). The spatial and temporal scales of hydrological processes play an important role in the upstream-downstream dimension of impact analysis (Blöschl and Sivapalan 1995; Sivapalan and Kalma 1995). As the scale of the catchment changes from small plots to the river basin, the nature and complexities of the linkages and related impacts change as well. Effects which occur at one scale, for example a micro catchment, might have a different magnitude and impact at another scale, for example the whole river basin. The scale issue becomes more complicated when the system components interact with each other, influencing the behavior of processes in space and time. Thus when analyzing upstreamdownstream relationships, it is important first to look at the particular problem or issue and clarify its scale.

Upstream-downstream linkages are particularly important in analyses of 'what-if' scenarios in the context of future change. This type of analysis focuses on how water availability and demand might change in the future, and what kind of adaptation measures should be designed to enable people to maintain their lives in the face of such changes. The projected impacts of climate change are complex and differ between various landscapes. Understanding the magnitude, extent, and duration of these impacts is still limited. Geoinformatic tools such as hydrological models complemented by GIS and remote-sensing analysis (Flügel 2011) can be instrumental in providing more reliable information and knowledge about potential impacts. Approaches of this type can be used to understand the behavior of a catchment under different scenarios (such as land use change and climate change) and how these scenarios are likely to affect the hydrological processes and future water availability.

\section{Addressing upstream-downstream linkages}

Recognition of the upstream-downstream linkages in a river basin means realizing that events that occur in the upper part of the basin have a direct influence downstream and that issues arising downstream can sometimes be addressed through interventions upstream. There are many ways in which the activities of those living upstream may influence the opportunities available to downstream inhabitants. Such impacts are generally more pronounced at a small-to-medium scale, but can also take effect at a larger scale. Typical examples might include polluted discharge in an upstream catchment that makes water downstream unusable; withdrawal of large amounts of water for irrigation upstream, leaving less water available downstream; as well as widespread land use change upstream which affects water availability and sediment loads downstream. Beneficial interventions might include flood mitigation measures and projects to balance seasonal water supply, such as developing small scale water storage over a wide area to capture excess runoff (Molden et al. 2014), maintaining vegetation cover to reduce erosion, and dam construction to provide electricity, water, and/or flood regulation for downstream users. Detailed discussion of the impact of planned interventions like construction of dams and irrigation schemes goes beyond the scope of this paper, but clearly, human intervention can affect hydrological dynamics on a large scale.

The complex nature of the linkages, the regional heterogeneity, and the different manifestations of change in the upstream areas highlights the need for a multisectorial and basin-wide approach to water resources management and thus the necessity for regional cooperation on water, and especially on water hazards. Water resources need to be considered from a holistic perspective, taking into account scenarios for supply and demand and promoting wise and balanced use to improve livelihood conditions. The ILWRM approach can be instrumental in looking for adaptive solutions to problems and also enable different stakeholders of upstream and downstream areas to work together for the better management of land and water resources. This approach has mainly been introduced at the smaller catchment scale, but should be extended to the whole river basin. While doing so, the specific circumstances of the upstream communities in the Himalayan region, who live in fragile and inaccessible mountain areas with limited resources and opportunities, should be taken into account so that incentive mechanisms can be established to encourage and acknowledge their contribution.

Plans for addressing issues or mitigating projected impacts downstream might involve changed behavior on the part of the upstream population. The important question remains: How can the upstream population be motivated to forgo their own immediate benefit in order to help those downstream? The concept of upstreamdownstream linkages is closely connected to the concept of environmental flows and environmental services. In terms of water, the upstream system is essentially providing an ESS in the form of water flow, and the upstream populations are the 'guardians' of this flow. There is a 
growing interest in mechanisms that can better recognize the value of ecosystem services and in developing incentive schemes built upon the two premises: (i) ecosystem services have a quantifiable economic value and that (ii) this value can be used to encourage investment in maintenance or restoration (Katoomba 2008). Payments for ecosystem services (PES) represent one such innovative approach (Tacconi 2012) that could be used to support implementation of ILWRM concepts within river basins.

PES is a market-based instrument for managing natural resources based on the concept of paying groups for the provision of environmental services to obtain more efficient environmental outcomes for the benefits of the larger community (Butle et al. 2008; Kosoy et al. 2007). In the context of water in the Himalayan catchments, this means compensating upstream communities for good catchment management that secures benefits for the downstream communities. Such payments could be used to increase livelihood opportunities and reduce the marginality of upstream communities, and could be derived by mobilizing a part of the benefits derived by the downstream communities, for example through taxation or royalties. Such an approach also facilitates communication and understanding between upstream and downstream resource users and managers, and encourages downstream users to focus on sustainable use of the resources that are now recognized to have a monetary value. The approach could be introduced at catchment level and then scaled up to the river basin level. PES is more complex on a large scale, especially across borders. Although international schemes have been designed for carbon payments, an approach of this sort remains to be developed for water at the basin level and will require the formulation of enabling policies and regulations by governments.

\section{Conclusions}

This review highlights the close upstream-downstream linkages in hydrological processes and water availability in the Himalayan region, but also underlines the limited understanding of these processes and their impacts in downstream areas resulting from the complexity and heterogeneity of the region, the lack of data, especially from upstream areas, and the impact of scale. To improve understanding of the linkages and the impacts of upstream events and activities in the near and far downstream, it is necessary to use an integrated systems analysis approach, and to have more and better data and better coordinated data collection. This will provide a basis for integrated management of land and water resources both in individual catchments and across the entire river basin. Payment for environmental services offers a potential mechanism for implementing activities identified using the integrated management approach and should be further investigated.

The major findings of this review can be summarized as follows:

- The role of forest and other vegetation in, and the impacts of deforestation and cultivation on, runoff, base flow, and soil erosion are complex, and it is important not to draw conclusions from results focused on individual aspects of the process in isolation.

- Reduction in forest cover is likely to increase the average stream flow to downstream areas and vice versa in the shorter term. However, in the long term, accelerated erosion might cause the loss of soil profile, increase in overland flow, and decrease in baseflow.

- Overall, forest cover has only a limited influence on major flood events in the monsoon-dominated Himalayas, although it may influence smaller and more localized events.

- Vegetation cover hinders soil erosion, but the impact is mainly visible at a smaller catchment scale. The main source of sediment load in the Himalayan rivers at the river basin scale is believed to be natural erosion from the high Himalayas.

- Climate change is likely to affect the hydrological regime of the Himalayan rivers, with increased discharge overall, but with the increase adding to the high flows of the monsoon season with possibly lower discharge in the dry season.

These findings lead to a number of recommendations:

- A conceptual framework should be developed based on integrated systems analysis as a basis for understanding the upstream-downstream linkages at both catchment and basin level depending upon the scale. The issue of scale is very important for the assessment. Different issues are relevant at varying scales, and the nature of the impacts varies as the scale changes.

- Overall, lack of data in the Himalayan region is hindering understanding of environmental processes. A concerted effort should be made to close the knowledge gaps through more focused and coordinated collection of relevant data, especially from the high mountain areas. At the same time, the uncertainties in the state of knowledge and the outcomes of scientific analysis should be clearly communicated in a way that is understandable to stakeholders and policy makers.

- An integrated land and water management approach should be developed at catchment and basin scales 
to ensure that interventions contribute to sustainable development as a whole and do not have detrimental impacts. Water resources need to be considered from a holistic perspective, taking into account scenarios for supply and demand, and promoting wise and balanced use of water resources to improve livelihood conditions.

- The most established benefit of forest cover is in controlling erosion and downstream sedimentation. This could be important for catchments and sub-basins where storage-type water resources infrastructure exists or is planned. Although the actual benefits of maintaining forest cover can differ from case to case, this may be a potential area for developing a payment for ecosystem services approach.

- The studies on climate change impacts on water resources do not suggest serious changes in the overall water availability in the future, but there may be changes in seasonal distribution and the occurrence of extremes.

- The possibility of using a payment for ecosystem services (PES) approach should be investigated as a means for supporting understanding and cooperation among the communities in the basin and of compensating upstream communities for good catchment management that secures benefits for the downstream communities. However, such a mechanism requires support and effective enforcement from strong policies and regulations.

\section{Abbreviations}

ILWRM: Integrated land and water resources management; HKH: Hindu Kush Himalayas; LULC: Land use land cover; NE: Natural environment; HD: Human dimension; ESS: Ecosystem services; ESF: Ecosystem functions; ISA: Integrated system analysis; RU: Response unit; GIS: Geographical information system; PES: Payment for ecosystem services.
}

\section{Competing interests}

The authors declare that they have no competing interest.

\section{Authors' contributions}

All authors contributed significantly to this work. SN designed the overall framework of this paper, conducted a thorough review of the literature, and developed the manuscript. WAF contributed to the overall manuscript and ILWRM and integrated system analysis. ABS contributed to the overall manuscript and climate change related information. All authors read and approved the final manuscript.

\section{Acknowledgements}

This study was funded in part by the Federal Ministry of Education and Research (BMBF), Germany, who provided research funds to S. Nepal under the International Postgraduate Studies in Water Technologies (IPSWaT) program, and in part by the Koshi Basin Programme at the International Centre for Integrated Mountain Development (ICIMOD), which is supported by the Australian Government through the Sustainable Development Investment Portfolio for South Asia. We are grateful to A. Mukherji for her critical inputs and suggestions on the paper. Thanks to A. Beatrice Murray for editing the language of the manuscript. Finally, I am thankful to the reviewer for the critical inputs and comments on the manuscript. All views and interpretations expressed in this publication are those of the author(s). They are not necessarily attributable to any of the institutions mentioned above.
Received: 24 April 2014 Accepted: 13 August 2014

Published online: 09 September 2014

\section{References}

Akhtar M, Ahmad N, Booij MJ (2008) The impact of climate change on the water resources of Hindukush-Karakorum-Himalaya region under different glacier coverage scenarios. J Hydrol 355(1-4):148-163

Alford D (1992) Hydrological aspects of the Himalayan region. International Centre for Integrated Mountain Development (ICIMOD), Kathmandu Nepal

Andreaassian V (2004) Waters and forests: from historical controversy to scientific debate. J Hydrol 291:1-27

Awasthi KD, Sitaula BK, Singh BR, Bajacharaya RM (2002) Land-use change in two Nepalese watersheds: GIS and geomorphometric analysis. L Degrad Dev 13(6):495-513

Bajracharya SR, Shrestha B (2011) The status of glaciers in the Hindu Kush-Himalayan region. International Centre for Integrated Mountain Development (ICIMOD)

Barnett TP, Adam JC, Lettenmaier DP (2005) Potential impacts of a warming climate on water availability in snow-dominated regions. Nature 438(7066):303-309

Beven K (2001) Rainfall-runoff modelling: the primer. Wiley, Chicester

Blaikie PM, Muldavin JSS (2004) Upstream, downstream, China, India: the politics of environment in the Himalayan region. Ann Assoc Am Geogr 94(3):520-548

Blöschl G, Sivapalan M (1995) Scale issues in hydrological modelling a review. Hydrol Process 9:251-290

Bosch JM, Hewlett JD (1982) A review of catchment experiments to determine the effect of vegetation changes on water yield and evapotranspiration. J Hydrol 55:3-23

Bronstert A, Niehoff D, Bürger G (2002) Effects of climate and land-use change on storm runoff generation: present knowledge and modelling capabilities. Hydrol Process 16:509-529

Brooks KN, Folliott PF, Gregersen HM, Thames JL (1991) Hydrology and the management of watersheds. lowa State University Press, lowa

Bruijnzeel LA (1990) Hydrology of moist tropical forests and effects of conversion: a state-of-knowledge review. UNESCO International Hydrological Programme, Paris

Bruijnzeel LA (2004) Hydrological functions of tropical forests: not seeing the soil for the trees? Agric Ecosyst Environ 104:185-228

Bruijnzeel LA, Bremmer CN (1989) Highland lowland interaction in the Ganges Brahmaputra River Basin - a review of published literature. International Centre for Integrated Mountain Development (ICIMOD), Kathmandu, Nepal

Butle E, Lipper L, Stringer R, Zilberman D (2008) Payments for ecosystem services and poverty reduction: concepts, issues, and empirical perspectives. Econ Dev Econ 13:245-254

Calder I, Hall R, Bastable H, Gunston H, Shela O, Chirwa A, Kafundu R (1995) The impact of land use change on water resources in sub-Saharan Africa: a modelling study of Lake Malawi. J Hydrol 170(1-4):123-135

Calder IR (2005) Integrated Land and Water Resources Management. In: Anderson MG (ed) Encyclopedia of Hydrological Sciences. John Wiley \& Sons, Ltd

Chang $H$ (2004) Water quality impacts of climate change and land-use changes in Southeastern Pennsylvania. Prof Geogr 56:240-257

Chang H, Franczyk J (2008) Climate change, land-use change, and floods: toward an integrated assessment. Geogr Compass 2(5):1549-1579

Christensen JH, Hewitson B, Busuioc A, Chen A, Gao X, Held I, Jones R, Kolli RK, Kwon W-T, Laprise R, Magaña Rueda V, Mearns L, Menéndez CG, Räisänen J, Rinke A, Sarr A, Whetton P (2007) Regional climate projections. In: Solomon S, Qin D, Manning M, Chen Z, Marquis M, Averyt KB, And MT, Miller HL (eds) Climate change 2007: the physical science basis. Contribution of Working Group I to the Fourth Assessment Report of the Intergovernmental Panel on Climate Change. Cambridge University Press, Cambridge, United Kingdom and New York, NY, USA

Costa MH, Botta A, Cardile JA (2003) Effects of large-scale changes in land cover on the discharge of the Tocantins River, Southeasterne Amazonia. J Hydrol 283:206-217

DeFries R, Eshleman KN (2004) Land-use change and hydrologic processes: a major focus for the future. Hydrol Process 18(11):2183-2186

Dixit A (2009) Kosi Embankment Breach in Nepal: need for a paradigm shift in responding to floods. Econ Polit Wkly 44(6):70-78

Dobler A, Yaoming M, Sharma N, Kienberger S, Ahrens B (2011) Regional climate projections in two alpine river basins: Upper Danube and Upper Brahmaputra. Adv Sci Res 7:11-20 
Douglass JE, Swank WT (1975) Effects of management practices on water quality and quantity: Coweeta Hydrologic Laboratory, North Carolina. In: Municipal Watershed Management Symposium Proceedings. USDA Forest Service Gen. Tech. Report NE-13, Northeastern Forest Experimental Station, pp 1-13

Eriksson M, Jianchu X, Shrestha AB, Vaidya RA, Nepal S, Sandström K (2009) The changing Himalayas: impact of climate change on water resources and livelihoods in the greater Himalaya. International Centre for Integrated Mountain Development (ICIMOD), Kathmandu

FAO, CIFOR (2005) Forests and floods: drowning in fiction or thriving in facts? Center for International Forestry Research and Food and Agriculture Organization of the United Nations, Bogor and Bangkok

FISRWG (1998) Stream corridor restoration: principles, processes, and practices. Federal Interagency Stream Restoration Working Group (FISRWG) (15 Federal agencies of the US gov't), GPO Item No. 0120-A, Washington, D.C

Flügel W-A (1995) Delineating hydrological units (HRU's) by GIS analysis for regional hydrological modelling using PRMS/MMS in the drainage basin of the River Broel, Germany. Hydrol Process 9(3-4):423-436

Flügel W-A (2000) Systembezogene Entwicklung regionaler hydrologischer Modellsysteme. Wasser and Boden, $52 \mathrm{Jg}, \mathrm{H}$ 3:14-17

Flügel W-A (2009) Applied geoinformatics for sustainable IWRM and climate change impact analysis. Technol Resour Manag Dev 6:57-85

Flügel W-A (2011) Geoinformatics concepts, methods and toolsets for comprehensive impact assessment and analysis of climate change for IWRM, Advances in Science and Research. Springer, TERI Press

Flügel WA, Bartosch A (2011) Analysis of present IWRM in the Upper Brahmaputra and the Upper Danube River Basins. Adv Sci Res 7:47-54

Gardner R, Gerrard AJ (2003) Runoff and soil erosion on cultivated rainfed terraces in the Middle Hills of Nepal. Appl Geogr 23(1):23-45

Gilmour DA, Bonell M, Cassells DS (1987) The effects of forestation on soil hydraulic properties in the Middle Hills of Nepal: a preliminary assessment. Mt Res Dev 7:239-249

Gole CV, Chitale SV (1966) Inland delta building activity of Kosi river. J Hydraul Div ASCE 91:111-126

Gomi T, Sidle RC, Richardson JS (2002) Understanding processes and downstream linkages of headwater systems. Bioscience 52(10):905-916

Goswami BN, Venugopal V, Sengupta D, Madhusoodanan MS, Xavier PK (2006) Increasing trend of extreme rain events over India in a warming environment. Science (80-) 314(5804):1442-1445

GWP (2000) Integrated water resources management, Technical Advisory Committee (TEC) 4. Global Water Partership (GWP)

Hamilton LS, King PN (1983) Tropical forested watersheds: hydrologic and soils response to major uses or conversions. Westview Press, Colorado

Hamilton LS, Pearce AJ (1987) What are the soil and water benefits of planting trees in developing country watershed? In: Sotygate DD, Sisinger JD (eds). Westview Press, Boulder CO, USA, pp 39-58

Hassan A, Wahid SM, Abdur M, Tanvir AR, Mazumder A, Sarker MH, Hossain HB, Mumu S, Sarker MH (2014) Climate change and water availability in the Ganges-Brahmaputra-Meghna basin: impact on local crop production and policy directives. In: Vaidya RA, Sharma E (eds). International Centre for Integrated Mountain Development (ICIMOD), Kathmandu Nepal

Heathcote IW, Edwards JR, Greener H, Coombs HM (1998) Integrated watershed management: principles and practice. Wiley, New York

Herron N, Davis R, Jones R (2002) The effects of large-scale afforestation and climate change on water allocation in the Macquarie River catchment, NSW, Australia. J Environ Manage 65(4):369-381

Hibbert AR (1967) Forest treatment effects on water yield. Pergamon, Oxford

ICIMOD (2009) Local responses to too much and too little water in the Greater Himalayan region. International Centre for Integrated Mountain Development (ICIMOD), Kathmandu

Immerzeel WW, van Beek LPH, Bierkens MFP (2010) Climate change will affect the Asian water towers. Science 328(5984):1382-1385

Immerzeel WW, Beek LPHV, Konz M, Shrestha AB, Bierkens MFP (2012) Hydrological response to climate change in a glacierized catchment in the Himalayas. Clim Change 110(3-4):721-736

Immerzeel WW, Pellicciotti F, Bierkens MFP (2013) Rising river flows throughout the twenty-first century in two Himalayan glacierized watersheds. Nat Geosci 6:742-745

Impat P (1981) Hydrometeorology and sediment data for Phewa Watershed: 1979 data. Phewa Tal Tech. Rep. No. 15. Department of Soil Conservation and Watershed Management, Ministry of Forests, Kathmandu
IPCC (2007) Climate change 2007: impacts. Adaptation and Vulnerability. Contribution of Working Group II to the Fourth Assessment Report of the Intergovernmental Panel on Climate Change. Cambridge University Press, Cambridge, UK, 976pp

Ives JD (2004) Himalayan perceptions: Environmental change and the well-being of mountain peoples. Routledge, London

Ives JD, Messerli B (1989) The Himalayan dilemma: reconciling development and conservation. The United Nations University, Routledge, London

Jodha NS (2002) Highland lowland linkages in the globalised world. In: Jodha NS, Bhadra B, Khanal NR, Richter J (eds) Poverty alleviation in mountain areas of China, Proceedings of the International Conference Held from 11-15 November, 2002. Chengdu, China

Katoomba (2008) Payments for ecosystem services: getting started: a primer. The Katoomba Group, UNEP and Forest Trends, Nairobi, Kenya

Kiersch B (2000) Land use impacts on water resources: a literature review, Discussion paper 1, FAO land and water bulletin 9.

Kosoy N, Tuna MM, Muradian R, Alier JM (2007) Payments for environmental services in watersheds: insights from a comparative study of three cases in Central America. Ecol Econ 61(2-3):446-455

Krause P (2002) Quantifying the impact of land use changes on the water balance of large catchments using the J2000 model. Phys Chem Earth 27(9):663-673

Kundzewicz ZW, Mata $\sqcup$, Arnell NW, Döll P, Kabat P, Jiménez B, Miller KA, Oki T, Sen Z, Shiklomanov IA (2007) Freshwater resources and their management. In: Climate change 2007: impacts, adaptation and vulnerability, Contribution of Working Group II to the Fourth Assessment Report of the Intergovernmental Panel on Climate Change. Cambridge University Press, Cambridge, UK

Laban P (1979) Landslides occurrence in Nepal. Department of Soil and Water conservation, Kathmandu, Nepal, cited in Tiwari, P.C., 2000. Land-use changes in Himalaya and their impact on the plains ecosystem: need for sustainable land use. Land use policy 17, 101-111

Liu X, Chen B (2000) Climatic warming in the Tibetan Plateau during recent decades. Int J Climatol 20:1729-1742

Lutz AF, Immerzeel WW, Shrestha AB, Bierkens MFP (2014) Consistent increase in High Asia's runoff due to increasing glacier melt and precipitation. Nat Clim Chang doi: 10.1038/nclimate2237.

Miller JT, Spoolman S (2012) Living in the environment: principles, connections, and solutions. Brooks/Cole Pub Co, Canada

Milliman JD, Meade RH (1983) World-wide delivery of river sediment to the oceans. J Geophys Res 91(1):1-21

Molden DJ, Vaidya RA, Shrestha AB, Rasul G, Shrestha MS (2014) Water infrastructure for the Hindu Kush Himalayas. Int I Water Resour Dev :1-18

Mool PK, Bajracharya SR, Joshi SP (2001) Inventory of glaciers, glacial lakes, and glacial lake outburst flood monitoring and early warning systems in the Hindu Kush-Himalayan Region - Bhutan. ICIMOD, Kathmandu, Kathmandu Nepal

Morgan R, Morgan D, Finney H (1984) A predictive model for the assessment of soil erosion risk. J Agric Eng Res 30:245-253

Mu J, Liu Q, Gabriel HF, Xu D, Xu J, Wu C, Ren H (2013) The impacts of climate change on water stress situations in the Yellow river basin, China. Irrig Drain 62(5):545-558

Nepal S (2012) Evaluating upstream-downstream linkages of hydrological dynamics in the Himalayan region, PhD. Thesis. Friedrich Schiller University of Jena, Jena

Nepal S, Adiga PB (2007) Linkages between watershed and irrigation, a case study on management practices of Farmer Managed Irrigation System (FMIS), Argali, Palpa, Nepal. In: Pradhan P, Uprety LP, Parajuli UN, Gautam U (eds). Irrigation in Transition: Interacting with Internal and External Factors and Setting the Strategy Actions: November 2006, Nepal, pp 94-102

Nepal S, Krause P, Flügel W-A, Fink M, Fischer C (2014) Understanding the hydrological system dynamics of a glaciated alpine catchment in the Himalayan region using the J2000 hydrological model. Hydrol Process 28(3):1329-1344

Pauleit S, Ennos R, Golding Y (2005) Modeling the environmental impacts of urban land use and land cover change-a study in Merseyside, UK. Landsc Urban Plan 71(2-4):295-310

Pfennig B, Kipka H, Wolf M, Fink M, Krause P, Flügel WA (2009) Development of an extended spatially distributed routing scheme and its impact on process oriented hydrological modelling results. In: Yilmaz KK, Yucel I, Gupta HV, Wagener T, Yang D, Savenije H, Neale C, Kunstmann H, Pomeroy J (eds) New approaches to hydrological prediction in data-sparse regions, Proceedings of Symposium HS. 2 at the Joint Convention of The International Association of Hydrological Sciences (IAHS) and The International Association of Hydrogeologists (IAH). IAHS Press, pp 37-43 
Ramsay WJH (1987) Deforestation and erosion in the Nepalese Himalaya - is the link myth or reality? in: Forest Hydrology and Watershed Management Proceedings of the Vancouver Symposium, August 1987: IAHS Publication No 167. IAHS. IAHS.

Rasul G (2014) Why Eastern Himalayan countries should cooperate in transboundary water resource management. Water Policy 16(1):19-38

Rees HG, Collins DN (2006) Regional differences in response of flow in glacier-fed Himalayan rivers to climatic warming. Hydrol Process 20(10):2157-2169

Sangjun I, Hyeonjun K, Chulgyum K, Cheolhee J (2009) Assessing the impacts of land use changes on watershed hydrology using MIKE SHE. Environ Geol 57:231-239

Schneeberger C, Blatter H, Ayako A-O, Wild M, Abeouchi A (2003) Modelling changes in the mass balance of glaciers of the northern hemisphere for a transient 2 X CO2 scenario. J Hydrol 282(1-4):145-163

Sharma KP (1997) Impact of land-use and climatic changes on hydrology of the Himalayan Basin: a case study of the Kosi Basin, Ph.D. thesis. University of New Hampshire.

Shrestha DP (1997) Assessment of soil erosion in the Nepalese Himalaya, a case study in Likhu Khola Valley, Middle Mountain region. L Husbandary 2(1):59-80

Shrestha AB (2008) Resource manual on flash flood risk managmeent. ICIMOD, Kathmandu

Shrestha AB, Wake CP, Mayewski PA, Dibb JE (1999) Maximum temperature trends in the Himalaya and its vicinity: an analysis based on temperature records from Nepal for the period 1971-94. J Climate 12(9):2775-2786

Shrestha AB, Wake CP, Dibb JE, Mayewski PA (2000) Precipitation fluctuations in the Nepal Himalaya and its vicinity and relationship with some large-scale climatology parameters. Int J Climatol 20(3):317-327

Shrestha AB, Wahid SM, Shrestha M, Molden DJ (2013) Regional water cooperation in the Hindu Kush Himalayan region. In: Griffiths J, Lambert R (eds) Free flow: reaching water security through cooperation. UNESCO Publishing.

Singh P, Bengtsson L (2004) Hydrological sensitivity of a large Himalayan basin to climate change. Hydrol Process 18(13):2363-2385

Singh P, Bengtsson L (2005) Impact of warmer climate on melt and evaporation for the rainfed, snowfed and glacierfed basins in the Himalayan region. J Hydrol 300(1-4):140-154

Singh P, Jain SK (2006) Snow and glacier melt in the Satluj river at Bhakra Dam in the western Himalayan region. J Hydrol 326:199-214

Singh P, Kumar N (1997) Impact assessment of climate change on the hydrological response of a snow and glacier melt runoff dominated Himalayan river. J Hydrol 193(1-4):316-350

Singh MP, Singh JK, Mohanka R (2000) Forest environment and biodiversity. Daya Publishing House, New Delhi

Singh SP, Bassignana-Khadka I, Karky BS, Sharma E (2011) Climate change in the Hindu Kush-Himalayas: the state of current knowledge. ICIMOD, Kathmandu

Siriwardena L, Finlayson BL, McMahon TA (2006) The impact of land use change on catchment hydrology in large catchments: the Comet River, Central Queensland, Australia. J Hydrol 326:199-214

Sivapalan M, Kalma JD (1995) Scale problems in hydrology: contributions of the robertson workshop. Hydrol Process 9(3-4):243-250

Stocking MA (1984) Rates of erosion and sediment yield in the African environment. In: Walling DE, Foster SSD, Wurzel P (eds) Challenges in African hydrology and water resources.

Tacconi L (2012) Redefining payments for environmental services. Ecol Econ 73:29-36

Thakur PK, Tamrakar NK (2001) Geomorphology, sedimentology, and hazard assessment of the Sapta Kosi alluvial fan in eastern Nepal. J Nepal Geol Soc 24(Specia):29-30

Thanapakpawin P, Richey PJ, Thomas D, Rodda S, Campbell B, Logsdon M (2007) Effects of land use change on the hydrologic regime of the Mae Chaem river basin, NW Thailand. J Hydrol 334:215-230

Thapa KB (2001) Water-induced disaster in the Himalaya: case study of an extreme weather event in central Nepal. In: Tianchi L, Chalise SR, Uprety BN (eds) Landslide problem mitigation to the Hindukush - Himalayas.

Tiwari PC (2000) Land-use changes in Himalaya and their impact on the plains ecosystem: need for sustainable land use. Land Use Policy 17:101-111

Walling DE (1999) Linking land use, erosion and sediments yields in river basins. Hydrobiologia 410:223-240

Wasson RJ (2003) A sediment budget for the Ganga Brahmaputra catchment. Curr Sci 84(8):1041-1047
Wasson RJ, Juyal N, Jaiswal M, McCullochd M, Sarinb MM, Jaine V, Srivastavac $P$, Singhvi AK (2008) The mountain-lowland debate: deforestation and sediment transport in the upper Ganga catchment. J Environ Manage 88:53-61

Watson RT, Verardo DJ (2000) Land use, land use changes and forestry. Cambridge University Press, Cambridge

Wilk J (2002) Simulating the impacts of land-use and climate change on water resource a availability for a large south Indian catchment. Hydrol Sci 47(1):19-30

Ya T, Nakarmi G (2004) Effect of contour hedgerows of nitrogen-fixing plants on soil erosion of sloping agricultural land. In: Ya T, Murry AB (eds) Impact of contour hedgerows: a case study. ICIMOD, Kathmandu

Zhang L, Dawes WR, Walker GR (1999) Predicting the effect of vegetation changes on catchment average water balance. Cooperative Research Centre for Catchment Hydrology, Technical Report 99/12, 35pp

doi:10.1186/s13717-014-0019-4

Cite this article as: Nepal et al:: Upstream-downstream linkages of hydrological processes in the Himalayan region. Ecological Processes 2014 3:19.

\section{Submit your manuscript to a SpringerOpen ${ }^{\circ}$ journal and benefit from:}

- Convenient online submission

Rigorous peer review

- Immediate publication on acceptance

- Open access: articles freely available online

- High visibility within the field

- Retaining the copyright to your article

Submit your next manuscript at $\gg$ springeropen.com 